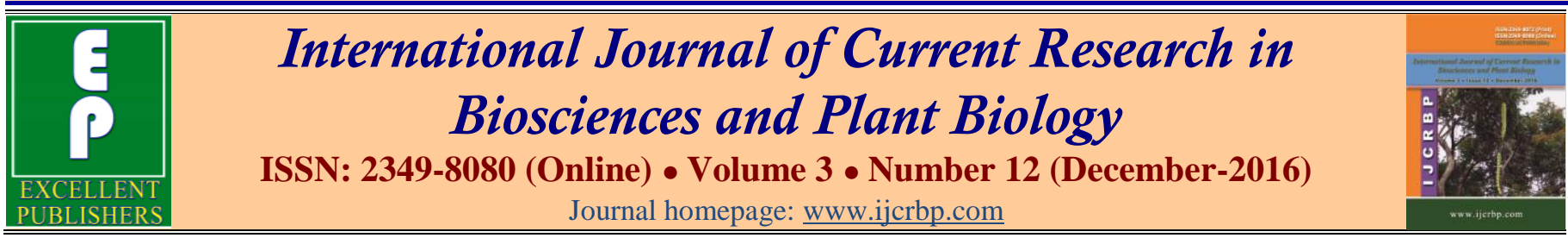

\title{
A Comparative Study on the Yields of Casein and Albumin in Buffalo and Two Dairy Milk Samples
}

\author{
Vaishnavi Bhat, Jahnavi Pamarthy, Shobham and M.K. Sukumaran* \\ Department of Biochemistry, Bhavan's Vivekananda College, Secunderabad-50o 094, Telangana, India \\ *Corresponding author.
}

\begin{abstract}
A b stract
The present study was carried out to compare the yields of casein and albumin in buffalo and dairy milk samples 1 and 2 over a period of 10 successive days. Milk contains highquality protein and fat. Presence of calcium, magnesium, selenium, riboflavin, vitamin B12 and pantothenic acid makes milk a nutritionally important component in human life. Results from our studies indicate that the mean values of casein content to be $5.53 \mathrm{~g} \%$ (buffalo milk sample), $3.56 \mathrm{~g} \%$ (dairy milk sample 1) and $3.38 \mathrm{~g} \%$ (dairy milk sample 2) over the 10 day isolation period. However, the casein content in buffalo milk sample was higher by about $2 \mathrm{~g} / \%$ as compared to dairy milk samples 1 and 2 . There was no significant variation in albumin content in all the 3 milk samples, buffalo milk sample [2.41g\%], dairy milk sample $1[2.27 \mathrm{~g} \%]$ and dairy milk sample 2 [1.95 g\%]).
\end{abstract}

\section{Article Info}

Accepted: 22 November 2016

Available Online: 06 December 2016

Ke ywords

Albumin

Casein

Buffalo milk

Commercial milk

Isoelectric point

\section{Introduction}

Milk is a complex mixture of the biological molecule that can serves as the primary food source for mammal's infant not only after their birth, but continue to consume for several months after their birth. It essentially contains, water, vitamins, minerals, proteins, carbohydrates and lipids that are essential for mammalian life (CHEM, 1021). Nutrients present in the milk samples of different animals is shown in Table 1.

Table 1. Milk components (\% composition).

\begin{tabular}{lllllll}
\hline Species & Water & Fat & Casein & Whey Protein & Lactose & Ash \\
\hline Cow & 87.3 & 4.4 & 2.8 & 0.6 & 4.6 & 0.7 \\
Buffalo & 82.2 & 7.8 & 3.2 & 0.6 & 4.9 & 0.8 \\
Goat & 86.7 & 4.5 & 2.6 & 0.6 & 4.4 & 0.8 \\
Sheep & 82.0 & 7.6 & 3.9 & 0.7 & 4.8 & 0.9 \\
Camel & 86.5 & 4.0 & 2.7 & 0.9 & 5.4 & 0.7 \\
\hline
\end{tabular}

Biological molecules present in milk play significant role in the proper functioning and maintenance of the body. Casein accounts for nearly $70-80 \%$ of the total proteins in bovine milk (Hoffman and Falvo, 2004). Milk appears white and opaque by the virtue of casein. Its existence in the colloidal particle (Micelle-casein combined with calcium and phosphorus) enables it to form a gel or clot in the stomach. The advantage of these clots is their ability to release the amino acids slowly into the blood stream (Boirie et al., 1997) thereby allowing the body to utilize retained nitrogen. Until the 1960s, the major nonfood applications of casein included adhesives for wood, 
in paper coating, leather finishing and in synthetic fibres, plastics for buttons, buckles etc. (Southward, 1998). In the past few years, edible grade casein was used in food industry as a stabilizer, moisture retainer etc.

In recent years, much of the emphasis is given to the development of high protein diets, especially for athletes (strength/power is required) and in many weight reduction programs (Hoffman and Falvo, 2004). In this regard, animal sources of dietary protein provide complete protein, numerous vitamins, and minerals. However, the major problems associated with food from animal origin are the presence of saturated fat relative to vegetable foods. With the ever-increasing food processing technologies, food industries are providing food supplement products that are derived from sources such as milk whey, casein, and soya (Hoffman and Falvo, 2004). Different applications of casein are provided in articles by Sutermeister (1927) and Darewicz et al. (2006). Since casein is widely used in non-food based industry, food industry, and dietary supplements, the present study was carried out to compare the yields of casein and albumin in buffalo and 2 commercially available milk samples.

\section{Materials and methods}

Milk samples: Buffalo milk sample was procured directly from the buffalo owners. Dairy milk sample 1 and 2 were procured from an identified milk booth. Samples were collected for a period of over 10 successive days. Casein and albumin were isolated on 10 successive days in duplicate samples according to published methods (Palleros, 2000; Pamarthy et al., 2016).

Isolation of casein: After warming $100 \mathrm{ml}$ of the milk sample to $40^{\circ} \mathrm{C}$, the $\mathrm{pH}$ was adjusted to 4.6 (isoelectric point of casein) with $10 \%$ acetic acid. At isoelectric point, casein precipitates out along with butter fat leaving a liquid component called whey. The precipitated casein was filtered through four layers of cheesecloth. The precipitated casein sample was successively washed with 95\% ethanol, ethanol: ether mixture in the ratio of 1:1 and finally with ether to remove unwanted fat and moisture. After the final wash, the precipitate was transferred on to a watch glass and dried at $40-50^{\circ} \mathrm{C}$ in an oven. After drying, the weight of casein was taken and the yield of casein was recorded as $\mathrm{g} \%$. All the milk samples were similarly treated.

Isolation of albumin: Immediately after the casein filtration, $2.5 \mathrm{~g}$ of powdered calcium carbonate was added to the filtrate (whey from the above casein isolated milk samples) and the solution was mixed thoroughly. The mixture was then brought to almost boiling for about 10 min; with continuous stirring. This treatment precipitated the remaining proteins (albumin). The precipitated albumin was filtered and dried at $40-50^{\circ} \mathrm{C}$ in an oven. After the albumin dried completely, the weight of albumin was taken and the yield of albumin was recorded as $\mathrm{g} \%$.

\section{Results and discussion}

Isolation of casein: Casein was isolated in duplicates from buffalo and dairy milk sample 1 and 2 over a period of 10 successive days and results are summarized in Table 2. As evident from the results presented in Table 2, the content of casein ranged between 5.93 to $5.19 \mathrm{~g} \%$ in the case of buffalo milk sample, 3.78 to $3.27 \mathrm{~g} \%$ in the case of dairy milk sample 1 and 3.79 to $3.14 \mathrm{~g} \%$ in the case of dairy milk sample 2 respectively over the 10-day isolation period.

Table 2. Casein content $(\mathrm{g} \%)$ in different milk samples.

\begin{tabular}{|c|c|c|c|c|c|c|c|c|c|}
\hline \multirow{2}{*}{$\begin{array}{l}\text { Day } \\
1\end{array}$} & \multicolumn{2}{|c|}{$\begin{array}{l}\text { Buffalo milk } \\
\text { sample }\end{array}$} & \multirow{2}{*}{$\begin{array}{l}\text { Average } \\
5.68\end{array}$} & \multicolumn{2}{|c|}{ Dairy milk sample 1} & \multirow{2}{*}{$\begin{array}{l}\text { Average } \\
3.58\end{array}$} & \multicolumn{2}{|c|}{ Dairy milk sample 2} & \multirow{2}{*}{$\begin{array}{l}\text { Average } \\
3.42\end{array}$} \\
\hline & 5.93 & 5.44 & & 3.50 & 3.67 & & 3.29 & 3.55 & \\
\hline 2 & 5.77 & 5.70 & 5.73 & 3.62 & 3.66 & 3.64 & 3.66 & 3.93 & 3.79 \\
\hline 3 & 5.67 & 5.24 & 5.45 & 3.74 & 3.60 & 3.67 & 3.46 & 3.47 & 3.46 \\
\hline 4 & 5.32 & 5.07 & 5.19 & 3.25 & 3.30 & 3.27 & 3.62 & 3.63 & 3.62 \\
\hline 5 & 5.52 & 5.47 & 5.49 & 3.55 & 3.43 & 3.49 & 3.33 & 3.43 & 3.38 \\
\hline 6 & 5.21 & 6.17 & 5.63 & 3.69 & 3.88 & 3.78 & 3.03 & 3.22 & 3.15 \\
\hline 7 & 5.51 & 5.93 & 5.72 & 3.52 & 3.21 & 3.45 & 3.56 & 3.28 & 3.42 \\
\hline 8 & 5.19 & 5.28 & 5.23 & 3.78 & 3.53 & 3.65 & 3.02 & 3.26 & 3.14 \\
\hline 9 & 5.19 & 5.30 & 5.24 & 3.67 & 3.80 & 3.73 & 3.27 & 3.16 & 3.21 \\
\hline 10 & 5.93 & 5.93 & 5.93 & 3.47 & 3.25 & 3.36 & 3.18 & 3.30 & 3.24 \\
\hline
\end{tabular}

Mean values of casein content in buffalo and dairy milk sample 1 and 2 over the 10-day isolation period is given in Fig. 1. It was observed that there were minor variations in the casein content on all the days of 
isolations. However, the casein content in the buffalo milk sample was higher by about $2 \mathrm{~g} \%$ as compared to dairy milk sample 1 and 2 .

Isolation of albumin: Albumin was isolated in duplicates from buffalo and dairy milk sample 1 and 2 over a period of 10 successive days and results are summarized in Table 3 . The content of albumin ranged between 2.57 to $1.95 \mathrm{~g} \%$ in the case of the buffalo milk sample, 2.24 to $1.75 \mathrm{~g} \%$ in the case of dairy milk sample 1 and 2.54 to $1.64 \mathrm{~g} \%$ in the case of dairy milk samples 2 respectively over the 10-day isolation period (Table 3 ).

Table 3. Albumin content ( $\mathrm{g} \%$ ) in different milk samples.

\begin{tabular}{|c|c|c|c|c|c|c|c|c|c|}
\hline & \multicolumn{2}{|c|}{ Buffalo milk } & \multirow{2}{*}{$\begin{array}{l}\text { Average } \\
2.44\end{array}$} & \multicolumn{2}{|c|}{ Dairy milk 1} & \multirow{2}{*}{$\begin{array}{l}\text { Average } \\
2.13\end{array}$} & \multicolumn{2}{|c|}{ Dairy milk 2} & \multirow{2}{*}{$\begin{array}{l}\text { Average } \\
2.00\end{array}$} \\
\hline 1 & 2.61 & 2.72 & & 1.97 & 2.30 & & 1.81 & 2.20 & \\
\hline 2 & 2.58 & 2.58 & 2.58 & 2.13 & 2.20 & 2.16 & 1.99 & 2.22 & 2.10 \\
\hline 3 & 2.45 & 2.55 & 2.50 & 2.06 & 2.10 & 2.08 & 1.87 & 1.83 & 1.85 \\
\hline 4 & 2.74 & 2.65 & 2.69 & 1.50 & 2.48 & 1.99 & 1.81 & 1.92 & 1.86 \\
\hline 5 & 2.79 & 2.45 & 2.62 & 1.86 & 2.10 & 1.98 & 1.93 & 1.84 & 1.88 \\
\hline 6 & 2.27 & 2.25 & 2.26 & 2.88 & 2.26 & 2.57 & 2.29 & 1.98 & 2.13 \\
\hline 7 & 2.60 & 2.19 & 2.39 & 2.40 & 3.11 & 2.75 & 1.87 & 1.93 & 1.90 \\
\hline 8 & 2.45 & 2.06 & 2.25 & 2.47 & 2.17 & 2.32 & 1.94 & 1.64 & 1.79 \\
\hline 9 & 2.10 & 2.28 & 2.19 & 2.24 & 2.54 & 2.39 & 2.04 & 1.97 & 2.00 \\
\hline 10 & 1.83 & 2.43 & 2.13 & 2.39 & 2.32 & 2.35 & 1.93 & 1.99 & 1.96 \\
\hline
\end{tabular}

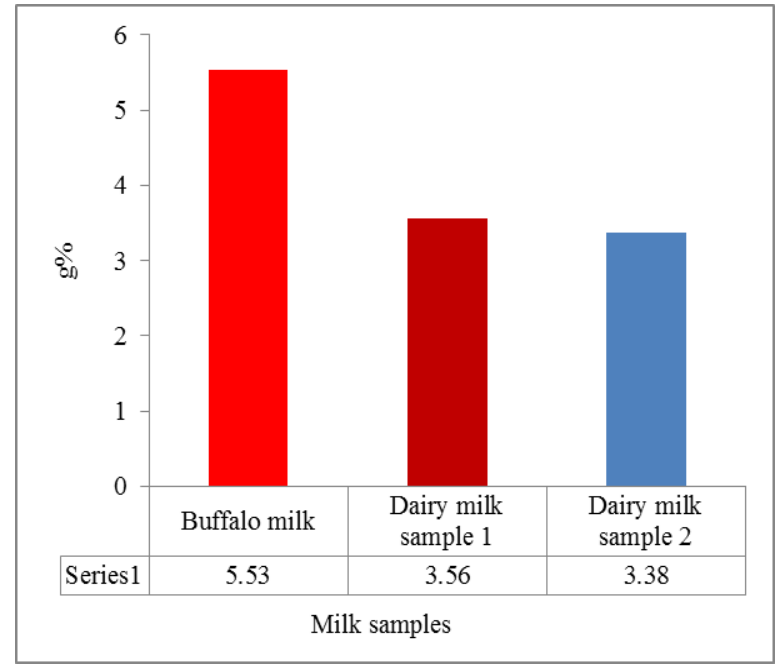

Fig. 1: Mean casein content in milk samples of 10-day isolation period $(\mathrm{g} \%)$.

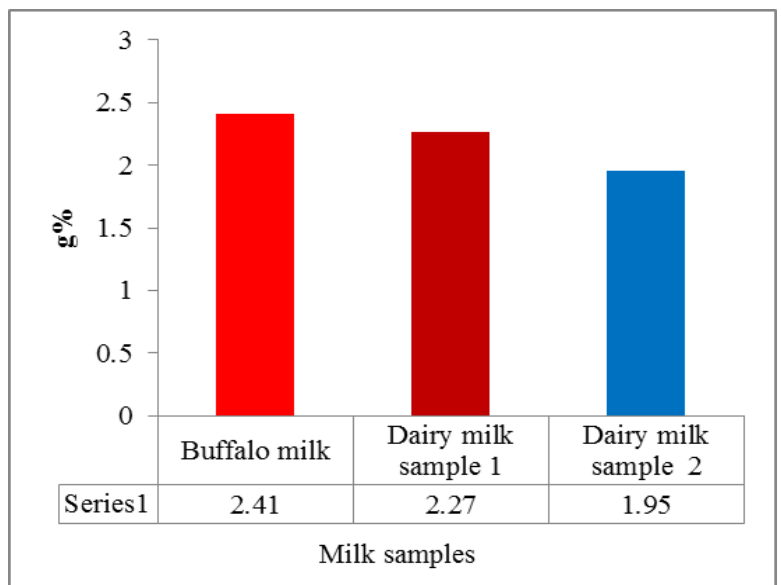

Fig. 2: Mean albumin content in milk samples of 10-day isolation period $(\mathrm{g} \%)$.
Mean values of albumin content in buffalo and dairy milk sample 1 and 2 over the 10-day isolation period is given in Fig. 2. It was observed that there were minor variations in the albumin content on all the days of isolations. Unlike the casein content which was higher in the buffalo milk sample, there was no noticeable variation observed in the case of albumin content on all the 10 day isolation period in all the 3 different milk samples.

\section{Conclusion}

Casein and albumin were isolated for 10 successive days in duplicate samples. The content of casein was found to range between 5.93 to $5.19 \mathrm{~g} \%$ (buffalo milk sample), 3.78 to $3.27 \mathrm{~g} \%$ (dairy milk sample 1) and 3.79 to $3.14 \mathrm{~g} \%$ (dairy milk sample 2) respectively. Casein content was higher by $2 \mathrm{~g} \%$ in the buffalo milk sample as compared to dairy milk sample 1 and 2 . The content of albumin ranged between 2.57 to $1.95 \mathrm{~g} \%$ (buffalo milk sample), 2.24 to $1.75 \mathrm{~g} \%$ (dairy milk sample 1) and 2.54 to $1.64 \mathrm{~g} \%$ (dairy milk sample 2) respectively. There was no noticeable variation observed in the case of albumin content in all the 3 milk samples.

\section{Conflict of interest statement}

Authors declare that they have no conflict of interest.

\section{Acknowledgement}

Authors are thankful to Management and Prof. Y. Ashok, Principal of Bhavan's Vivekananda College for providing necessary facilities and constant encouragement. 


\section{References}

Boirie, Y., Dangin, M., Gachon, P., Vasson, M.P., Maubois, J.L., Beaufrere, B., 1997. Slow and fast dietary proteins differently modulate postprandial protein accretion. Proc. Nat. Acad. Sci. (USA). 94, 14930-14935.

CHEM-1021, 2016. Isolation of casein from milk. Department of Chemistry, Austin Peay State University. Retrieved from

https://www.apsu.edu/sites/apsu.edu/files/chemistry/SP11 _1021_ISOLATION_OF_PROTEINS_FROM_MILK.pdf

Darewicz, M., Dziuba, J., Dziuba, M., 2006. Functional properties and biological activities of bovine casein proteins, and peptides. Pol. J. Food Nutr. Sci. 15/56 (SI 1), 79-86.

Hoffman, J. R., Falvo, M. J., 2004. Protein-which is best? J.
Sports Sci. Med. 3, 118-130.

Palleros, D. R., 2000. Chemistry of milk: Isolation of lactose and casein from milk. In: Experimental Organic Chemistry. John Wiley \& Sons, Inc., UK.

Pamarthy, J., Bhat, V., Sukumaran, M.K., 2016. A comparative study on casein and albumin contents in cow and commercial milk samples. IOSR J. Dental Med. Sci. 15(1), 102-106.

Southward, C. R., 1998. Casein Products in Chemical Processes in New Zealand. Vol. 2. (Eds.: Packer, J. E., Robertson, J., Wansbrough, H.). III-Dairy-E-Casein: 1-13, New Zealand Institute of Chemistry, Auckland, New Zealand. Available online at: http://nzic.org.nz/Chem Processes/ dairy/3E.pdf.

Sutermeister, E., 1927. Casein and Its Industrial Applications. The Chemical Catalog Company Inc., New York, USA.

\section{How to cite this article:}

Bhat, V., Pamarthy, J., Shobham, Sukumaran, M.K., 2016. A comparative study on the yields of casein and albumin in buffalo and two dairy milk samples. Int. J. Curr. Res. Biosci. Plant Biol. 3(12), 95-98. doi: http://dx.doi.org/10.20546/ijcrbp.2016.312.011 